now for many years tried electricity, and proved its powerful remedial agency in various diseases, $I$ can most conscientiously advise its use in any future unfortunate case of anæsthesia that may occur, as well as in the asphyxia that follows an overdose of prussic acid, and also in narcotism following the abuse of opium, or any other vegetable poison.

In either case, so confident am I of its power and efficacy, that I should feel myself very uncomfortable had I not a machine, and an efficient one, at hand, to fly to immediately in case of an untoward accident.-I am, Sir, your obedient serrant,

Princes-street, Coventry-street. J. H. Horne, Surgeon.

\section{TESTIMONIAL TO DR. BERNCASTLE.} To the Editor of The Lavoet.

SrR,-I beg, through the medium of your columns, to call on the profession generally to subscribe, for the purpose of presenting to Dr. Berncastle a testimonial expressive of our sympathy in his cause, and our disgust at the conduct of the coroner, jury, and guardians.

I shall be happy to receive subscriptions from gentlemen in my neighbourhood, and will set down, as a commencement, $£ 5$, for myself and two friends. I propose that the sum collected be presented to Dr. Berncastle in the form of a purse, to be by him laid out as he may think fit.

In making this appeal to my professional brethren, I trust I need not remind them that it is their duty and interest both, to rally round an injured member of their community, for what is his lot to-day, to-morrow may be their own.

I am, Sir, your obedient servant

Lewisham, Feb. 1848 C. Wilson Steel.

\section{FRIGHTFUL MORTALITY AMONGST MEDICAL PRACTITIONERS IN IRELAND.}

PROPOSALS FOR THE SUCCOUR OF THEIR FAMILIES.

To the Editor of THE LANCET.

Srr,-I sincerely trust that the melancholy details which you have given of the truly frightful mortality among our professional brethren in Ireland during last year, have been perused with thoughtful attention by every reader of your widely-circulated journal. One in abont every fourteen of the nedical practitioners of that country swept off in the course of twelve months !- a rate of mortality greatly exceeding the average in the unhealthiest climates in the world. That the fatal fever was, in almost every instance, caught from attendance upon the sick, is just what we might have expected; nor can any one wonder at the frequency of this result, if he will but realize to his mind for a moment the condition of a man, worn out, it may be, at the time with fatigue and anxiety, visiting the wretched inmates of an Irish hovel,-the very focus of destitution and filth at the best of times. I verily believe that there is not a spot on the face of the wide world where medical practitioners have to undergo such exhausting and unremunerative toil, and are exposed to greater danger in the discharge of their holy mission-that of ministering to the diseased-than in many of the districts of Ireland, where fever is epidemic through the land. Not to allude to other distressing circumstances in their position, I see it mentioned by Drs. Cusack and Stokes that the residences of the practitioners are sometimes so far apart from each other, that when one of our brethren has been himself overtaken with the pestilence, he has actually died without having received any professional attendance! When we learn at the same time that a family is thereby, in very many instances, left utterly unprovided for, must not the feeling of a strong sympathy at once take the place of a mere regret? Let the reader but look back at that account of destitution and suffering in some of the families, which you have given from the Report of the $\mathbf{M e}$ dical Temporary Relief Committee, and I am sure that his heart must burn with in him to do something to mitigate such distress. Ought we not, as a body, (I speak to my professional brethren in every part of the United Kingdom,) to inquire into the state of things as represented in that Report, in order that steps may be taken to afford assistance to the bereaved sufferers? There is a "Benerolent Fund Society" in Dublin, presided over and conducted by the leading physicians and surgeons of Ireland, the object of which institution is to relieve medical men under severe and urgent distress, occasioned by sickness, accident, or any other calamity; but the means at their disposal are utterly inadequate to the end in view. That most energetic friend of his brethren, Mr. Wilde, has, in the last number of the Dublin Quarterly Journal, appealed to the profession generally in aid of the Society at the present time. Now might we not make it the almoner of our bounty? - and as its active members have an exact acquaintance with the real condition of every applicant, we should have the satisfaction of knowing that the funds committed to their care would be faithfully and judiciously applied.

I could have wished much that some prominent and influential member of our ranks had taken up this subject, so that a prompt and efficient response might have been anticipated to the suggestion thrown out. I cordially hope, however, that my humble attempt may not have been made altogether in vain ; and in conclusion beg to say, that nothing will give me greater pleasure than to work with and under any gentleman or body of gentlemen who may think that my services can be of any use in promoting the good cause.

February, 1848 .

Gavin Mrlrox, M.D.

\section{POOR-LAW MEDICAL RELIEF,-LORD ASHLEY'S RESOI,UTIONS.}

To the Editor of The LaNCET.

SiR,-In your last two numbers of THE LANCET I find Lord A shley is about bringing certain resolutions before the House of Commons, respecting the poor-law medical officers, nearly all of which are very old, and have been in operation for years-I may say all, except that part relating to their salaries. In March, 1842, certain orders were issued by the Poor-Law Commissioners, and article twenty related to the medical officer's permanent appointment, \&c. My appointment was conferred in that year. Consequently, I am now appointed for life, or until I resign, or am disqualified. In June, 1847, a fresh number of orders were issued, and article 191 still further confirms article twenty, in 1842. Consequently, I do not see that Lord Ashley is going to do such great things for us, $-\mathrm{I}$ am, Sir, yours, \&c.,

a Union Medical Officer of Twelve Years' Standing.

\section{To the Editor of The LANCET.}

Sin,-In reference to the resolutions about to be submitted to the House of Commons for the medical treatment of the poor, by Lord Ashley, I beg to observe that the fifth resolution excludes members of the College of Surgeons unless they possess also a public medical degree or licence. Consequently, the great majority of the medical officers of the army and navy would be excluded from those civil appointments when they may retire from the service; as the diploma of the College of Surgeons, though indispensable, is the only collegiate qualification required from candidates for public employment, yet they are also required to produce testimonials of adequate medical studies in all branches of the profession, and to undergo examinations before the respective Boards; yet they could be objected to, notwithstanding their practical experience, and their acquired acquaintance with sanitary measures, so strictly enforced in the public services. This in itself would be a hardship to the medical officers, and probably an injury to the public; but it would, moreover, by implication, prove a serious detriment to retired officers entering private practice, as the question might be asked-" How can you consult an army doctor? they are not fit or qualified men to attend the poor!"

I would, then, hope that members of the College of Surgeons, having served in the army or navy for five years, may be included in the fifth resolution as competent persons.

Douglas, Isle of Man, Feb. 1848.

Yours, \&c.,

L. $\mathrm{S}$.

\section{NEW MEDICAL REGISTRATION COMMITTEE.- THE NATIONAL INSTITUTE. To the Editor of THr Lavcet.}

Sir,-It is with feelings of infinite pleasure that I read in your journal of last week of the nomination of the members of the new committee for inquiring into that perplexing subject, medical reform, or better regulation of the medical profession. Sincerely do I hope, and am confident I do not by any means stand alone in my desire, that ere this session of Parliament shall have passed away, your untiring endeavours and zeal for the great body of surgeons, civil, naval, and military, will ultimately produce some permanent benefit to all. Much as there is to contend with, nothing seems to me so absurd as the striving of a body, self-styled the National Institute, and whose actions are continually receiving wholesome reproof from your powerful pen. That their boastings about head and home can have any operation upon the legislature, I cannot for one moment conceive; or that the House of Commons can believe that they are the representatives of that great body, the English surgeons, is too ridiculous for me to entertain the slightest idea. There are enough medical corporations now for granting degrees, and ascertaining the fitness of candidates to practise the science of medicine, and the several branches of knowledge connected with 
it, and it does not at all seem likely to me, that were that not the case, the self-called National Institute (but without one atom of nationality in it-national, I presume, meaning, in its most limited sense, "public" or "general," whereas I cannot find that this exalted body possesses any such properties) would be selected for those purposes. When students work hard for their diplomas, they expect, and that rightly enough, that they will bear the signatures of individuals eminent, in the highest degree, in the different branches of their profession, whose names in themselves would give a dignity and shed a lustre over their hard sought-for prize. That this could not be the case with this fresh-adrertised clique-the offspring of a rapidly decaying licensing bodymust be apparent to all. How is it, I would ask, that the students think so much of their diploma from the Royal College of Surgeons of England, but from the fact of its being connected with the names of eminent and learned individuals? and how is it that the M.D. is now so common in general practice, numbers of whom are practising without perhaps ever knowing where the Blackfriars' establishment is situated, but that they consider it a greater honour than the L.A.C.? Ind:ed, that this latter Company might be very well dispensed with, as regards medical examination, is now the opinion of all, except those who, as you justly state, wish to graft themselves upon the old stock, and thus endeavour to thrust themselves forward, by name alone, as the advertised head and home of the surgeons of this ccuntry, or, as they call themselves, of medicine, surgery, and midwifery. We have those two time-honoured institutions, the Colleges of Physicians and Surgeons, whose by-gone members have scattered such a bright halo around the profession of medicine, and whose present ones are known herever English science is heard of and respected. Surely these, if any hodies can be, are fully competent to examine in all the branches which necessarily belong to medieal study; where, then, can this puffing Institute, unknown except in the advertising columns, find ground to take its stand? Again: we have that noble fountain of learning, the University of London, whose degrees are everywhere held in the highest estimation; and if the A pothecaries' Company, who, in their day, have well executed the task assigned to them of examining, are considered at the present time to be unnecessary as a licensing body, where can another corporation, in every way inferior, find room to rear its insignificant head? Well, indeed, do you believe that the surgeons of England will not allow themselves to be bound to an inferior institution: no greater insult can be offered; neither is such a thing likely to be, I trust, while the Colleges of Physicians and Surgeons occupy a station in this country. Wishing you all success in your arduous position, and that you may be enabled to see the result of your highly honourable undertaking, I am, Sir, your obedient servant,

Mortlake, Surrey, Feb, 1848.

\section{THE CROYDON INQUEST.-PROPOSITION FOR THE CIRCULATION OF "THE LANCET LEADING} ARTICLE."

\section{To the Editor of TuE LANCET.}

Srr, - I beg very respectfully to suggest to the profession, but to poor-law medical officers in particular, that a copy of the leading article on the Croydon Inquest, contained in THE LANCET of Saturday, Jan. 29th, now published in the form of a small pamphlet, be immediately transmitted to every member of parliament, and to the editors of the metropolitan press.

This may be accomplished by an outlay of a few pounds, and I have little doubt that the sowing of such seed will produce a tenfold return. It affords an opportunity of impressing on the minds of the legislature the arduous duties which the medical officer has to undergo, and of illustrating the gross wrongs with which he has to contend. This opportunity ought not to be lost. Members of Parliament require instruction on medical points, and, I believe, will courteously receive it, when its object is to expose a system of terrible injustice. Let us take every means, then, to enlighten Parliament, and in proportion as we succeed in that, so will our efforts redound to our own advantage.

Six hundred and fifty-eight copies, at $8 s$. per hundred, will amount to $£ 212 s .6 d$., say $£ 3$. Postage stamps, to $£ 214 s$. 10d., say $£ 3$. Then there will be payment to the secretary who shall undertake to address and forward them. For $£ 10$, therefore, the business may be fully carried out, and a small subscription from those who take an interest in this matter (and who does not?) will at once realize the amount required.

If this suggestion meet with approval, I shall have much pleasure in transmitting my quota of any subscription which may be deemed necessary.

I have the honour to be, Sir, your obedient servant, Cheapside, Halifax, Feb. 1848. Frederick Smrth Garurck.

\section{ASIATIC CHOLERA.}

To the Editor of THe LanceT.

SIr,-Will that dreadful scourge the cholera visit our island again? and if so, are medical men prepared to wage war against it? I ask this on these grounds:-In a conversation with my family medical attendant, $\mathrm{I}$ inquired-If myself, wife, or children, should be attacked with cholera, what mode of treatment would you adopt? His reply was, "I scarcely know; there are so many remedies proposed." As a husband, and father of five lovely children, what must my feelings have been at this reply? I admired the candour of my medical friend, in whom I had the greatest confidence, but told him that if the cholera should visit my house he must excuse my calling him in.

Can you tell me, Sir, to whom I may apply in such a case of need; for perhaps many other medical men may not have made up their minds on the subject. May I be allowed, through your raluable journal, to propose that meetings should be held in different localities, that the remedies already tried and those proposed be fairly discussed, and that some mode of treatment, which may be decided upon by the majority, be laid before the Board of Health, or at a general meeting of medical men, and adopted if so approved. That a resolution amongst themselves be passed, that every medical man shall forward to a certain body, appointed for that purpose, his success, or non-success, in the treatment of every case that may fall under his care, with the remedies adopted, whatever they might be. A statistical account of deaths and recoveries being kept, and reported in the medical journals, with mode of treatment \&c., would enable the profession to draw their conclusions, and no one in future wonld have to say, "Why I scarcely know ; there are so many remedies proposed."

February, 1848 .

I am, Sir, your obediert serrant.

\section{ON SUMMONING MEDICAL WITNESSES AT INQUESTS.}

In a letter addressed to us, in reply to Mr. French's last communication to the Editor of THE LANCET, Mr. Redford remarks:-

"Mr. French imagines (though how is a puzzle, for he quotes my words) that I say a certain surgeon gave "a false certificate of death." If he refer to his own letter, he will see my words quoted correctly, as "a certificate of death," meaning that the surgeon, having attended the deceased, was perfectly convinced as to the cause of death, and was enabled to fill up the certificate accordingly, althongh the death might have been sudden, and not during an attendance,-- circum. stances sufficient to warrant an inquest, thongh one might not have been absolutely necessary. Now such a certificate would not be a false certificate, as Mr. French absurdly imagines. The assumed case which follows in the letter is a preposterous creation, as totally irrelevant as the remarks about "Medical Reform Act, and expulsion from professional ranks, the hopelessness of parish surgeons escaping censure, and the high principles absolutely necessary to sustain a parish surgeon in his office for seventeen years." Your readers will observe that, though Mr. French tries to insinuate that the instances given by me are untrue, he has never attempted to deal with the facts, they remain firm and unassailed, and, I have reason to believe, will be confirmed and more fully laid before you by those gentlemen in whose experience they occurred, and others of my acquaintance, who, so far from joining in the sentiments of Mr. French, have expressed their thanks to me for taking the trouble to discuss the matter."

Golden-square, Feb. 1848 .

\section{A DEFINITION OF QUACKERY. To the Editor of Thy LanozT.}

SIR,-I addressed a note to you some months ago, for the purpose of recording the death of an old man from Holloway's pills; and, at the same time, I drew your attention to the fearful progress of quacks and quackery in the manufacturing districts - from the peripatetic venders of cough lozenges and worm powders, to the exhibitors of the bubbles and sugarmilk of homeopathy. A certain notorious practitioner of the "do-nothing" system, who was then, and is still, carrying matters with a high hand in this neighbourhood, was mightily irate and indignant at being classed with his compeers; but a man's deeds, not his professions, must be the proof of his orthodoxy.

I say, that that man, who, to get practice, proclaims himself a philanthropist, desirous of benefiting his species, not anxious for money, who gulls by his professions and gratuitous attend. 